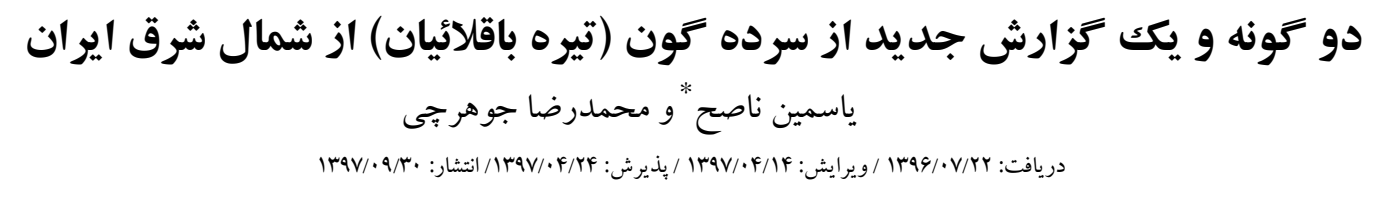

كروه گياه شناسى، يزوهشكده علوم گياهى، دانشكاه فردوسى مشهد، مشهد، ايران Naseh-ya@staff.um.ac.ir مسئول مكاتبات

جكيده. ضمن بر رسى نمونهاى گياهى جمع آورى شده متعلق به بخش Ammodendron از سرده Astragalus موجود در هرباريوم يزوهشكده علوم گياهى

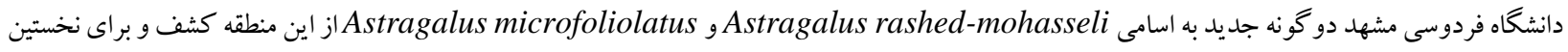

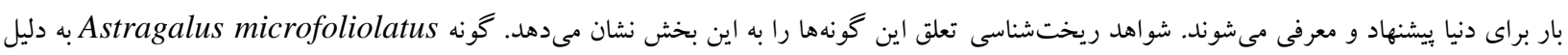

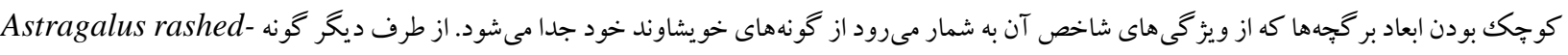
mohasseli

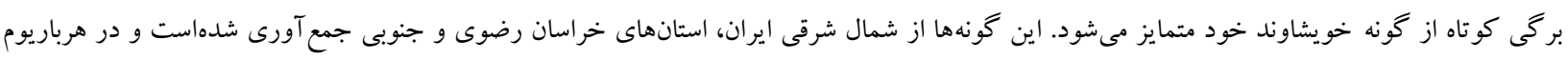

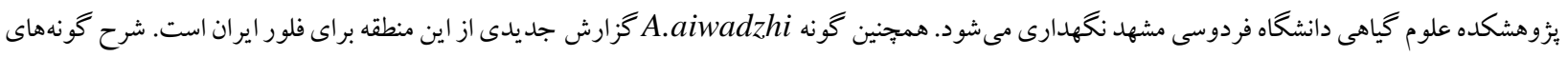

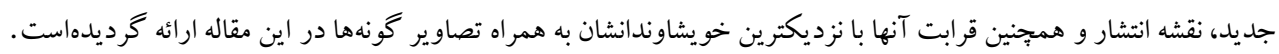

وازههاى كليدى.آمو دندرون، استانهاى خراسان، ايرانوتورانى، تاكسونومى، صفات ريختى

\title{
Two new species and a new record of the genus Astragalus (Fabaceae) from NE Iran
}

\author{
Yasamin Nasseh* \& Mohammad Reza Joharchi \\ Received: 14.10.2017 / Revised: 05.07.2018 / Accepted: 15.07.2018/ Published: 21.12.2018
}

Research Center for Plant Sciences, Ferdowsi University of Mashhad, Mashhad, Iran

*Correspondent author: Naseh-ya@staff.um.ac.ir

\begin{abstract}
During the study on the specimens of Astragalus sect. Ammodendron in the herbarium of Ferdowsi University of Mashhad (FUMH), based on the last and most recent sources, two new species, i.e. A. microfoliolatus sp. nova and A. rashed-mohasseli sp. nova were found and described. Morphological evidence confirmed that the belonging of these taxa to Astragalus sect. Ammodendron. The most important differences between A. microfoliolatus and its closest relatives are leaflets with very small size and glabrescent legume. Also, the main distinctive characters of $A$. rashed-mohasseli are the presence of hairs on the dorsal side of vexillum, oblong legume and short rachis. Hairy vexillum has been obseverd for the first time in this section. In addition, A. aiwadzhi is recorded as a new species for the flora of Iran. Taxonomic descriptions, illustrations and distribution maps are provided to expedite identification.
\end{abstract}

Keywords. Ammodendron, Irano-Turanian, Khorassan provinces, morphological characters, taxonomy 


\section{INTRODUCTION}

Astragalus L. (Linnaeus, 1753) is the largest genus of flowering plants with approximately 3000 species worldwide. Section Ammodendron Bunge (Bunge, $1868,1869)$ is one of the most complex groups among those covered with bifurcate hairs. Astragalus sect. Ammodendron was first established by Bunge with 19 species. According to recent studies, however, this group includes approximately 80 species worldwide of which $35-40$ species and 25 endemics are distributed in Iran (Rechinger et al., 1961; Maassoumi, 1998, 2005; Podlech et al., 2010; Ghahremaninejad, 2004a,b, 2005; Ghahremaniejad \& Gaskin, 2004; Nasseh et al., 2010, 2012; Dastpak et al., 2011; Podlech \& Zarre, 2003, 2013). Iran is one of the most genetically diverse hotspots of Astragalus with about 826 species (Ghahremaninejad, 2015).

The plants in this section are shrubby or subshrubby, often becoming more or less leaflet-less with age. After the development of the stems, they are densely covered with appressed medifixed, white hairs. Stipules are often membranaceous, somewhat adnate to the petiole or almost free. Petioles and rachises are sometimes hard and spiny. Leaflets are found in 1-3 pairs, rarely unifoliate. Inflorescences are usually lax with short or long peduncules. Bracteoles are absent. Calyces are campanulate or nearly so and not inflated in fruit. Pods coriaceous, include 2 locules, slightly longer than the calyx, sessile to stipitate, valves densely covered with soft, long, appressed or spreading, basifixed hairs, sometimes mixed with short medifixed hairs or rarely glabrous (Podlech \& Zarre, 2013).

Phytogeography. The diversity center of Astragalus section Ammodendron is the Turkestanian floristic Province (Takhtajan, 1986) of the Irano-Turanian region. The members of this group are vastly distributed in the Armeno-Iranian Province of the aforementioned region. The great majority of species of sect. Ammodendron (Maassoumi, 1998; Podlech \& Zarre, 2003, 2013; Podlech et al., 2010) occurs in Middle Asia, Egypt (Sinai), Turkey, Saudi Arabia, Near East, Caucasus region, Iran (mainly in the central, southern and eastern parts of Iran) and Afghanistan and Pakistan (Ghahremaninejad, 2004b; Podlech \& Zarre, 2013). They are mostly psammophytes or associated with more or less sandy substrata, in dry and semidesertic regions and very rarely petrophilous plants of foothills and low mountains. (Ghahremaninejad, 2004b; Podlech \& Zarre, 2013).
The aim of the present work is to study the taxonomy of the genus Astragalus section Ammodendron with a focus on collected materials from NE Iran. Since Middle Asia in Irano-Turanian region is the main diversity center of Astragalus sect. Ammodendron (Komarov, 1946; Maassoumi, 1998), the vicinity of Razavi Khorassan province to this area resulted in the occurrence of many species of this section in NE Iran.

\section{MATERIALS AND METHODS}

Herbarium specimens of the genus Astragalus sect. Ammodendron in the herbarium of Ferdowsi University of Mashhad, (FUMH) were revised. Studies were carried out by using different floras and resources (Gontscharov, 1946; Maassoumi, 2005; Podlech \& Zarre, 2010, 2012, 2013) and related taxonomic literatures (Bunge, 1868, 1869; Gontscharov, 1946; Rechinger et al., 1961; Maassoumi, 1998, 2005; Podlech et al., 2010; Ghahremaninejad, 2004a,b, 2005; Ghahremaninejad \& Gaskin, 2004; Nasseh et al., 2010, 2012; Dastpak et al., 2011; Podlech \& Zarre, 2003, 2013). The most important characteristics of the examined specimens were the size and shape of leaflets, the characteristics of inflorescence comprising the length of peduncle and raceme, the size of calyces and the type and color of their hairs, the number of flowers, the shape and size of the legume and their indumentum types.

\section{RESULTSAND DISCUSSION}

\section{Taxonomic treatment}

\section{New taxa to the world}

1. Astragalus microfoliolatus Nasseh, sp. nova (Figs. 1, 2; Tables 1, 2)

Type: Iran. Razavi Kohrassan: N Torbat-e Heydariyeh, Robatsang, 4 October 1991, 1650 m, Joharchi \& Zangooei 21038! (Holotype: FUMH!; Isotype: $\mathrm{T}$ !).

Diagnosis: Differt ab A. squarrosus Bunge: Foliis 2$5 \times 1.5-2 \mathrm{~mm}$ (nec 5-12 × 1.5-4 mm). Rachis 0.2-0.7 cm longi (1-4 cm). Bracteae $0.5 \mathrm{~mm}$ longi (nec 1-1.5 $\mathrm{mm}$ ). Calyx 5-6 mm longi, subtus pilis obsita paulatim glabrescens (nec 6-8 $\mathrm{mm}$, dense pilosa). Leguminibus 4.5-5.5 mm longi, subtus pilis obsita paulatim glabrescens (nec 6-8 $\mathrm{mm}$, dense pilosa). 


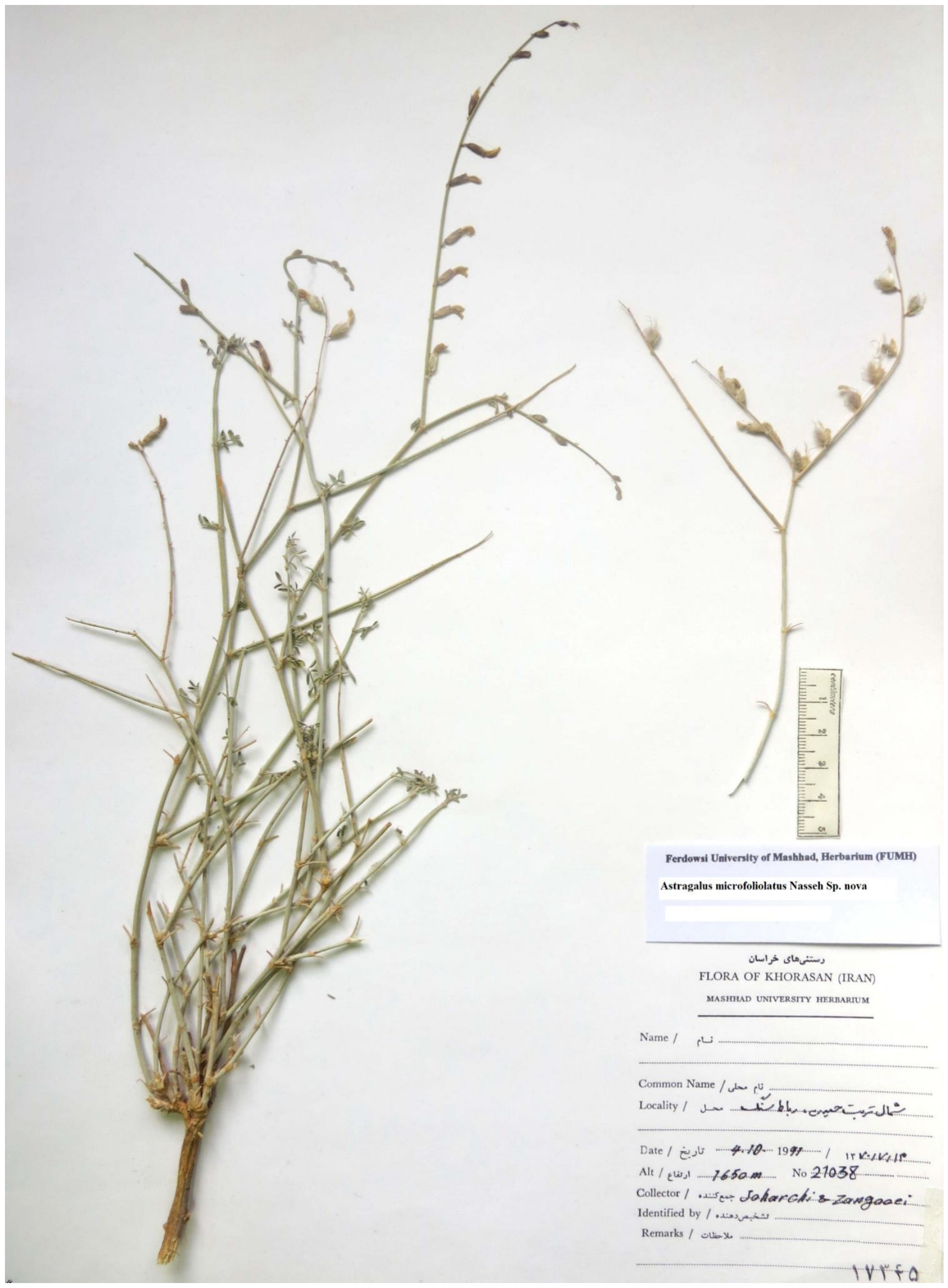

Fig. 1. A. microfoliolatus Nasseh; Joharchi \& Zangooie 21038 (Photo by H. R. Sharghi). 
Table 1. Comparison of A. microfoliolatus \& A. squarrosus

\begin{tabular}{lll}
\hline & A. microfoliolatus & A. squarrosus \\
\hline Leaflet & & $5-12 \times 1.5-3(-4)$ \\
Rachis $(\mathrm{cm})$ & $2-5 \times 1.5-2$ & $1-3(-4)$ \\
Bract $(\mathrm{mm})$ & $0.2-0.7$ & $1-1.5$ \\
Calyx $(\mathrm{mm})$ & 0.5 & $6-8$ \\
& $5-6$ & covered with dense hairs \\
& covered with sparse hairs & \\
\hline
\end{tabular}

Table 2. Some floral and vegetative parts of the new Astragalus species

\begin{tabular}{|c|c|c|c|c|c|c|c|c|}
\hline Leaflet & legume & Ovary & Stamen & Carina & Wing & Standard & Calyx & Species \\
\hline 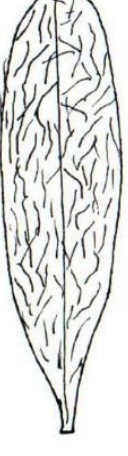 & & & gopoge & 章 & 调 & & And & 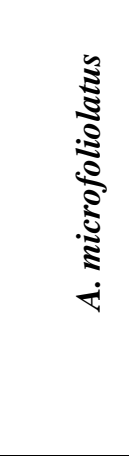 \\
\hline 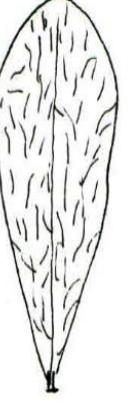 & & & & ( & s & ij) & Am and & 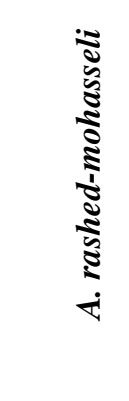 \\
\hline
\end{tabular}

Description: Plants perennial, up to $35 \mathrm{~cm}$ tall, suffruticose, branched, densely covered with medifixed appressed white hairs. Stipules 1-1.5 mm long, membranous, shortly adnate to the petiole, sparsely appressed white hairy. Rachis very short up to $7 \mathrm{~mm}$ long; leaflets mainly 2 pairs rarely 1 , obolng to elliptic, $2-4 \times 1.5-2 \mathrm{~mm}$, mainly acute, rarely obtuse, on upper side subglabrous to glabrous, on underside densely hairy. Peduncles $0.5-1.5 \mathrm{~cm}$ long, densely covered with medifixed appressed hairs. Racemes 3-13 cm long, covered with medifixed appressed hairs, 4-12 flowered. Bracts ca. $0.5 \mathrm{~mm}$ long, membranous, ovate, subglabrous. Pedicel ca. $1.5 \mathrm{~mm}$ long, white hairy. Calyx 5-6 mm long, campanulate to tubular, covered with medifixed appressed white hairs; teeth short triangular, $1 \mathrm{~mm}$ long, hairy on outer and inner side. Corolla yellow when drying; standard ca. $11 \mathrm{~mm}$ long, elliptic, wings 10.5-11 $\mathrm{mm}$ long, limb ca. $5 \mathrm{~mm}$ long, oblong, claw 5.5-6 mm long, auricle small, less than $0.5 \mathrm{~mm}$ long; keel 10-1.5 mm long; limb ca. $5 \mathrm{~mm}$ long, elliptic-oblong, claw ca. $5 \mathrm{~mm}$ long, auricle very short. Legumes ca. $5 \mathrm{~mm}$ long, ovate, covered with basifixed spreading hairs on little tubercles, without short hairs, with a short glabrous stipe ca. $1 \mathrm{~mm}$ long, glabrous and a short beak ca. $0.75 \mathrm{~mm}$ long.

Flowering and Fruiting period: May-June.

Paratype: Iran. Razavi Khorassan: Torbat-e Heydariyeh-Mashhad road, Robatsang, 20.8.1986, Ayatollahi \& Zangooei 14998! (FUMH). 
Discussion: Astragalus microfoliolatus is a new endemic species, its distribution being restricted to a limited mountainous area with a temperate to arid climate in Razavi Khorassan, NE Iran. It has been collected only from the type locality. This species is very close to $A$. squarrosus, with some differences in morphological characters summarized in Table 3. On the basis of IUCN Red List categories and criteria
(IUCN, 2010) this species is classified as critically endangered. Therefore, a conservation program for this species is highly recommended.

Etymology: The name of the Astragalus microfoliolatus for the new species is proposed due to its very little leaflets.

Table 3. Comparison of $A$. rashed-mohasseli \& A. macrobotrys

\begin{tabular}{|c|c|c|}
\hline character ${ }^{\text {species }}$ & A. rashed-mohasseli & A. macrobotrys \\
\hline Ovary $(\mathrm{mm})$ & $\begin{array}{l}8-9 \times 1-1.5 \text {, oblong, covered } \\
\text { with tangled homomorphic } \\
\text { hairs }\end{array}$ & $\begin{array}{l}5-7 \times 2 \text {, ellipsoid, covered } \\
\text { with heteromorphic, long } \\
\text { and short hairs }\end{array}$ \\
\hline Rachis (cm) & $0.2-1$ & $1.5-3$ \\
\hline Standard & hairy, limb rumboid & $\begin{array}{l}\text { glabrous, limb obovate and } \\
\text { rotundate at the apex }\end{array}$ \\
\hline
\end{tabular}

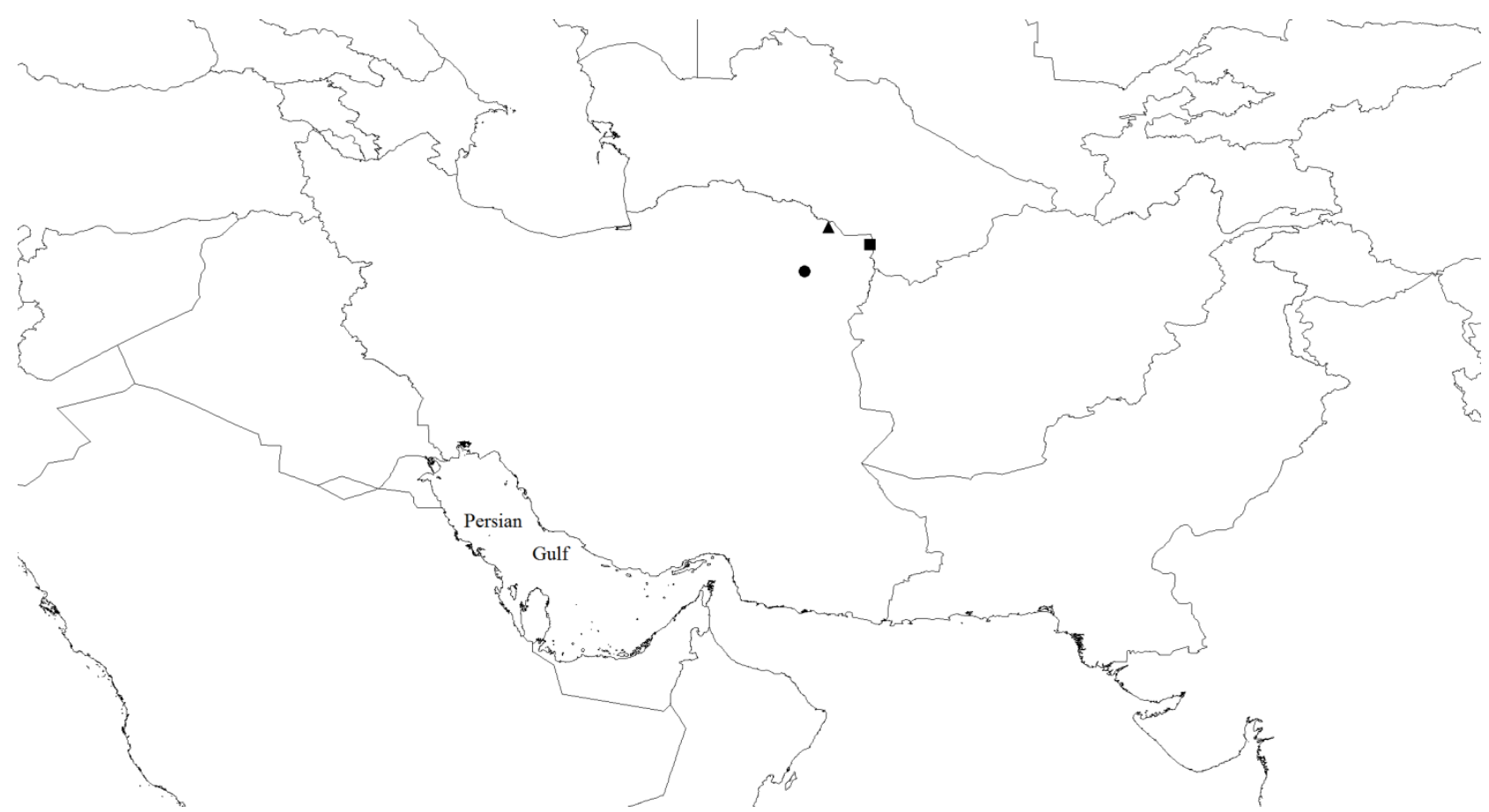

Fig. 2. Distribution Map: • Astragalus microfoliolatus, $\mathbf{\Delta}$ Astragalus rashed-mohasseli, $\mathbf{\square}$ Astragalus aiwadzhi.

2. Astragalus rashed-mohasseli Nasseh, sp. nova (Figs. 2, 3; Tables 2, 3)

Type: Iran. Razavi Khorassan, SE Kalat-e Naderi, between Hamam-Ghale \& Baba-Faraji, N 36 52' 28.31 " E 59 53' 54.26", 970 m, 10 June 2009, Joharchi 42985 (Holotype: FUMH!; Isotype: T!).
Diagnosis: Differt ab A. macrobotrys Bunge: Rachis $0.2-1 \mathrm{~cm}$ longi (nec 1-3.5 cm). Vexillum rhomboid, pilosi (nec obovato, apice rotundatum, non glabrescens). Ovary 8-9 mm oblonga (nec 5-7 mm, ellipsoidea). 


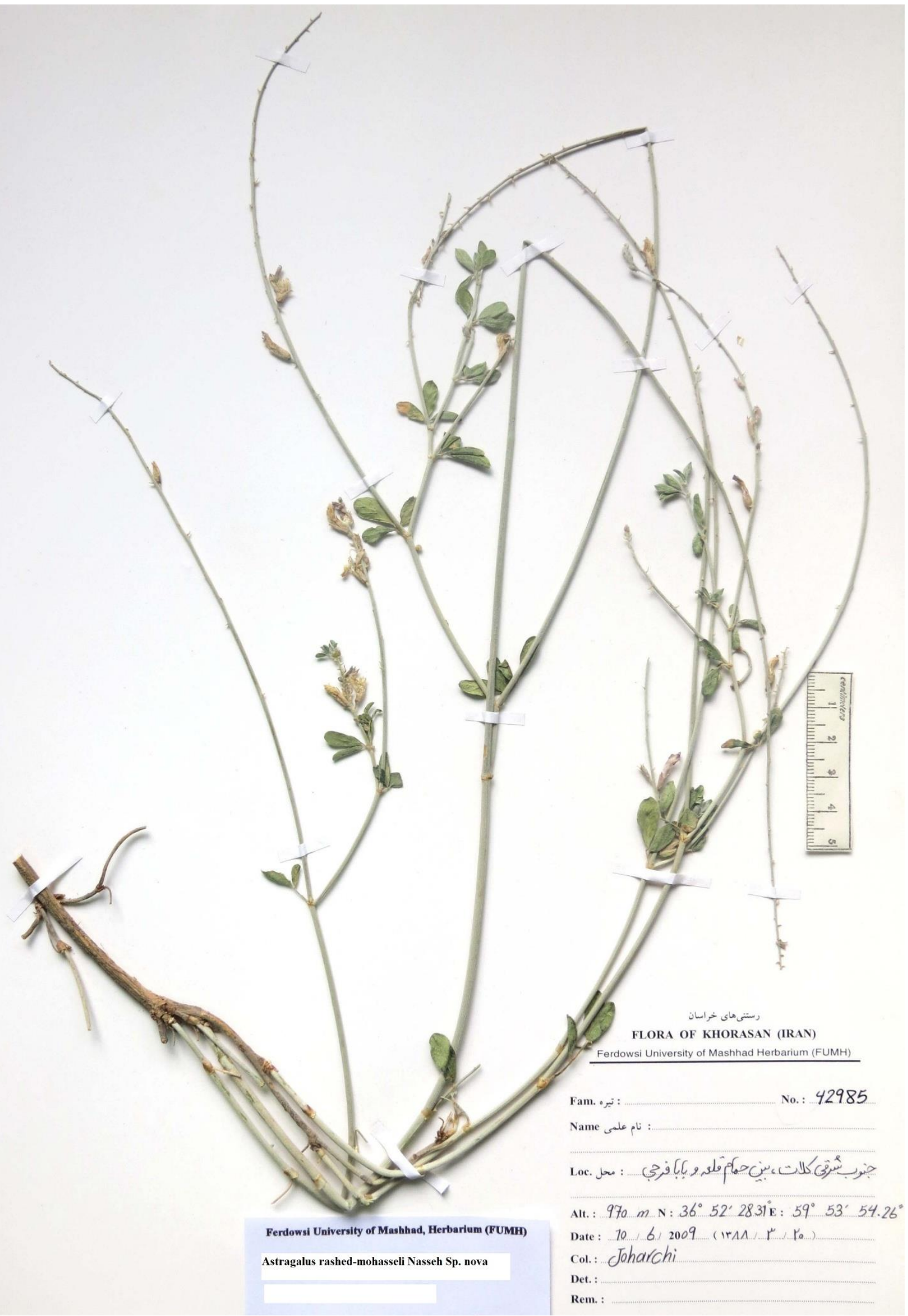

Fig. 3. A. rashed-mohasseli Nasseh; Joharchi 42985 (Photo by H.R. Sharghi). 


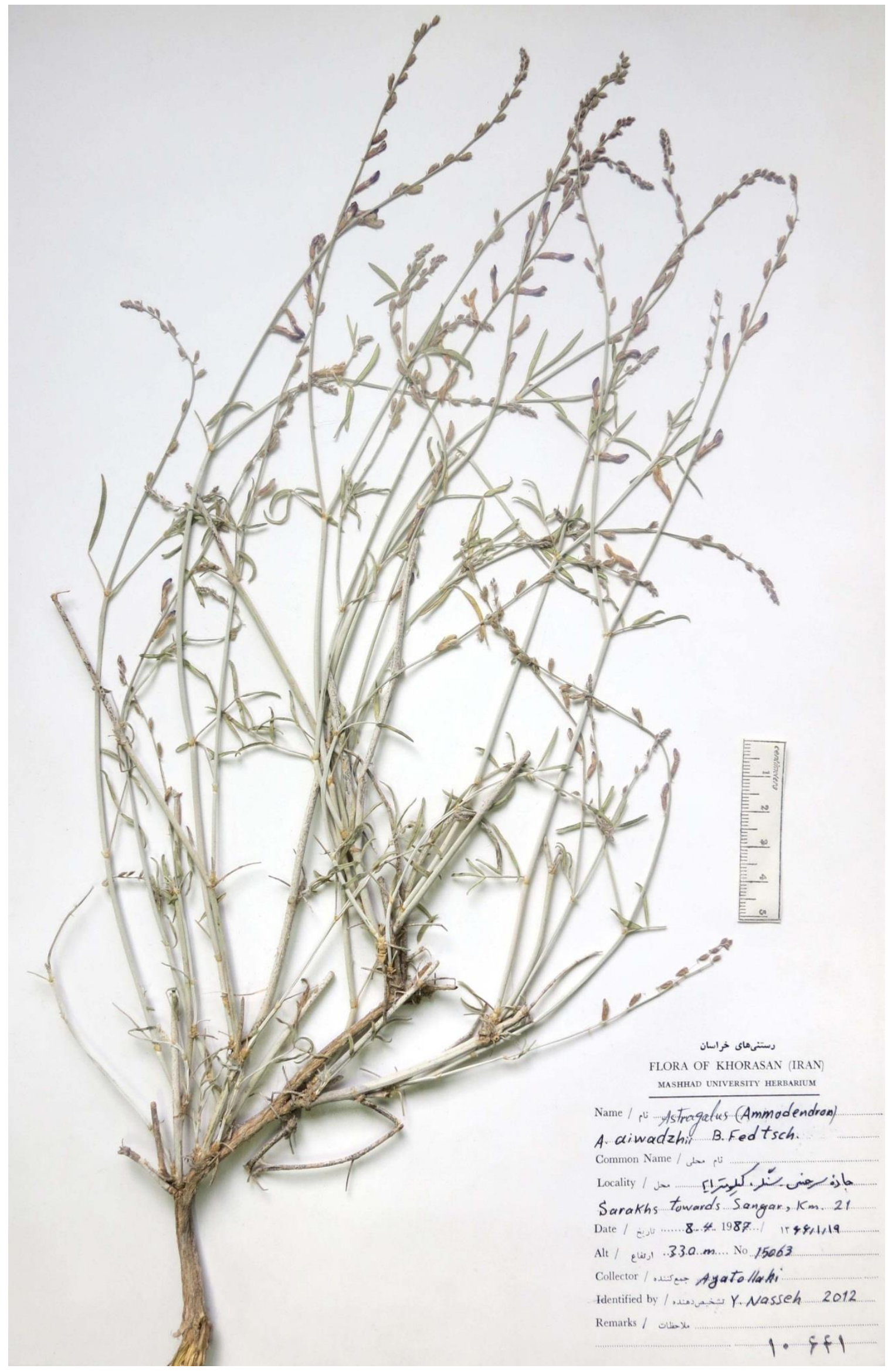

Fig. 4. A. aiwadzhi B.Fedtsch.; Ayatollahi 15063 (Photo by H.R. Sharghi). 
Description: Plants perennial, up to $65 \mathrm{~cm}$ tall, suffruticose, branched, covered wih medifixed appressed white hairs. Stipules 1.5-4 mm long, membranous, adnate to the petiole, somewhat vaginate and connate, nearly with free tips triangular, sparsely hairy or subglabrous. Rachis $2-10 \mathrm{~mm}$ long. Leaflets in 1-2 pairs, 7-15 $\times 3-7 \mathrm{~mm}$, elliptic to obovate, rounded at apex, on upper side sparsely hairy to subglabrous, on underside densely medifixed appressed hairy. Peduncles (1-) 3-7 cm long. Racemes (3-) 5-20 cm long when flowering, (8) 10-30 flowered. Bracts 1-2 $\mathrm{mm}$ long, ovate, membranous, very sparsely white and black hairy, sometimes sparsely ciliate at the margins. Pedicels 1$2 \mathrm{~mm}$ long, white hairy. Calyx 4.5-5.5 mm long, campanulate-turbinate, covered with medifixed, appressed white haris, very rarely mixed sparsely black hairs; teeth 1-2 mm long, narrowly triangular to triangular, sparsely hairy on inner side. Corolla yellow to pale violet when drying. Standard ca. 12 $\mathrm{mm}$ long, limb 6.5-7 mm long, rhombic-elliptic, plicate at margin, hairy on outer side in upper part, claw $5 \mathrm{~mm}$ long; wings $10.5-11 \mathrm{~mm}$ long, limb ca. 5 $\mathrm{mm}$ long, oblong, claw 6-6.5 mm long, auricle up to $0.5 \mathrm{~mm}$; keel $10 \mathrm{~mm}$ long limb ca. $5 \mathrm{~mm}$ long, claw $5.5 \mathrm{~mm}$. Stamen 9.5-10 mm long. Ovary oblong, substipitate, only covered with long, tangled hairs. Legume unknown but based on the ovary character, it might be oblong.

Flowering and Fruiting period: May-June

Discussion: Astragalus rashed-mohasseli is a new species which has been collected from Kalat-e Naderi, a small part of Razavi Khorassan, NE Iran. This type locality is a temperate mountainous area. Collected only from the type locality mentioned before, this species is very close to A. macrobotrys, being different from the latter in the characteristic of their standards due to the existence of hairs on the former (Table 1). On the basis of IUCN Red List categories and criteria (IUCN 2010) this species is classified as critically endangered, therefore, a conservation program for this species is highly recommended.

Etymology: This species is dedicated to Professor Dr. Mohammad-Hassan Rashed-Mohassel (Ferdowsi University of Mashhad), the former Head of the FUMH herbarium.

\section{New Record to Iran}

Astragalus aiwadzhi B.Fedtsch., Not. Syst. Leningrad 8: 166 (1940). (Figs. 2, 4)

Iran. Razavi Khorassan: $21 \mathrm{~km}$ of Sarakhs towards Sangar, N 36 21' 7.1994"E 61 8' 13.2"30 March 1987, Ayatollahi 15063! (FUMH).
Description: Plants perennial, up to $55-65 \mathrm{~cm}$ tall, subshrub, branched; ligneous older branches up to 25 $\mathrm{cm}$ long, grayish; branches of the current year 20-55 $\mathrm{cm}$ long. Stipules 2-2.5 mm long, membranous, totally connate, bidentate sparsely hairy or subglabrous. Rachis 1.5-3 cm long. Leaflets in lower parts usually in two pairs, in upper parts in one pair, $1.5-4.5 \mathrm{~cm} \times 2-3 \mathrm{~mm}$, linear acute densely covered on both sides with appressed white hairs. Peduncles $1.5-3 \mathrm{~cm}$ long. Racemes loose, $10-20 \mathrm{~cm}$ long with15-20 flowers. Bracts lanceolate $1.5(-2) \mathrm{mm}$ long, ovate, membranous, very sparsely white ciliolate. Pedicels 1-1.5 mm long, white hairy. Calyx 6-7 mm long, campanulate-cylindric, covered with medifixed, appressed white haris, very rarely mixed sparsely black hairs; teeth 1-1.5 mm long, narrowly triangular to triangular, sparsely hairy on inner side. Corolla yellow to pale violet when drying. Standard 11-12 mm long, limb rounded-oval, side in upper part claw $5 \mathrm{~mm}$ long; wings 10-11 mm, Limb oblong; keel 9-10 mm long. Legumes narrowly ellipsoid, 6-8 $\mathrm{mm}$ long, 2-3 $\mathrm{mm}$ high, with a short beak and a stipe $0.5-1 \mathrm{~mm}$ long; valves covered with spreading white long and short hairs.

This species has been described and introduced from Tadjikistan in ditione Schaartus, Vallis Bischkent, inter Pagos Aiwadzhet Czaschmy (Gontscharov, 1946).Here we report it as a new record for the first time from Iran.

\section{ACKNOWLEDGEMENT}

We would like to appreciate Research Council of Ferdowsi University of Mashhad for their financial support of the research project no. 851. Also, we sincerely thank Hamid-Reza Sharghi for the photographs.

\section{REFERENCES}

Bunge, A. 1868-1869. Generis Astragali species Gerontogeae. Pars prior, Claves Diagnosticae. Mémoriesde l'Académie Impérialdes sciences de Saint Petersburg. Septiémesérie. 7, 11: 1-140. Parsaltera, Specierum enumeratio., ser. 11 (16): 129 (1868); I. C. 15 (1): 2269 p.

Dastpak, A., Maassoumi, A.A., Kazempour Osaloo, S., and Nejadsattari, T. 2011. Astragalus ghamishluensis (Fabaceae), a new species of sect. Ammodendron from Iran. - Iran J. Bot. 17: 175-177.

Ghahremaninejad, F. 2004a. Value of trichom characters for separation of bifurcating hairy Astragalus L. (Fabaceae) at the sectional level. - Turk. J. Bot. 28: 241-245.

Ghahremaninejad, F. 2004b. The sections of Astragalus L. with bifurcating hairs in Iran. - Turk. J. Bot. 28: 101-117. 
Ghahremaninejad, F. 2004c. Astragalus baharensis (Fabaceae), a new species from NE Iran. - Ann. Bot. Fenn. 41: 143-145.

Ghahremaninejad, F. and Gaskin, J.F. 2004. A new species of Astragalus (Fabaceae, Atari be Gakegeae) from Iran. - Novon. 14: 431-433.

Ghahremaninejad, F. 2005. Astragalus hekmat-safaviae (Fabaceae), a new species from Iran. - Ann. Bot. Fenn. 42: 313-315.

Ghahremaninejad, F. 2015. Notes about Astragalus (Leguminosae) in Iran. - Ann. Naturhist. Mus. Wien. B 117: 279-281.

Gontscharov, N.F. 1946. Astragalus. - In Komarov, V.L. (ed.) Flora of the U.S.S.R. vol. 12. - Moskovaand Leningrad. $681 \mathrm{p}$.

Komarova, V.L. 1940. Botanicheskie materialy gerbariya botanicheskogo Instituta Imeni Akademii Nauk S SS R. Leningrad. Leningrad [St. Petersburg] vol. 8: 166.

Linnaeus, C. von. 1753. Species Plantarum, vol. 2. Laurentius Salvius, Stockholm. 755 p.

Maassoumi, A.A. 2005. The genus Astragalus in Iran, vol. 5 Research Institute of Forests and Rangelands, Tehran $786 \mathrm{p}$.

Maassoumi A.A. 1998. Old world check-list of Astragalus. Research Institute of Forests and Rangelands, Tehran $617 \mathrm{p}$.

Nasseh, Y., Joharchi, M.R. and Maassoumi, A.A. 2010. Two new species of the genus Astragalus sect. Ammodendron (Fabaceae) from Iran. - Iran J. Bot. 16: 221-224.

Nasseh, Y. and Joharchi, M. R. 2012. New records and new synonym of Astragalus sections
Ammodendron and Caprini (Fabaceae) from Iran. Iran J. Bot. 18 (1): 76-83.

Podlech, D. and Zarre, Sh. 2003. New species of Astragalus sect. Ammodendron (Fabaceae) with a key for the species of the Flora Iranica area. Willdenowia. 33: 314-352.

Podlech, D., Zarre, Sh., Maassoumi, A.A., Ekici, M. and Sytin A. 2010. Astragalus sect. Ammodendron. In Rechinger, K.H. (ed.), Flora Iranica. vol. 178: 373 403. - Naturhistorischen Museum, Wien.

Podlech, D., Maassoumi, A.A. and Zarre, Sh. 2012. Astragalus sect. Ammodendron. - In Rechinger, K.H. (ed.), Flora Iranica. vol. 179, 312 p. Naturhistorischen Museum Wien.

Podlech, D. and Zarre, Sh. 2013. A taxonomic revision of the genus Astragalus L. (Leguminosae) in the Old World. vols. 1-3. Naturhistorisches Museum Wien. 2439 p.

Rechinger, K.H., Dulfer, H. and Patzak, A. 1961. Sirjaevii fragmenta astragalogica XV. Astragalus sect. Ammodendron-Sitzungsber. Oesterr. Akad. Wiss., Mathem. - Natur. Kl., Abt. 170: 35-53.

$$
* * * * *
$$

How to cite this article:

Nasseh, Y. and Joharchi, M. R. 2018. Two new species and a new record of the genus Astragalus (Fabaceae) from NE Iran. -Nova Biol. Reperta 5 (3): 311-319. 